\title{
DEGRADATION BEHAVIOUR OF LIMESTONE CONCRETE UNDER LIMITED TIME SODIUM EXPOSURE
}

\author{
Anil Kumar Sharma ${ }^{1}$, Das S.K ${ }^{2}$, Parida F.C ${ }^{3}$. \\ ${ }^{1,2,3}$ Safety Engineering Division, Indira Gandhi Centre for Atomic Research, Kalpakkam. \\ Email: 1aksharma@igcar.gov.in
}

\section{Abstract}

Sodium leak on concrete structures lead to substantial damage due to thermal and chemical attack. Limestone concrete is widely used on floor, housing sodium components. The present study focuses on degradation behavior of limestone concrete under limited time exposure at $550^{\circ} \mathrm{C}$ in open air. The reduction in its compressive strength after interaction with liquid sodium was about $29 \%$. Chemical analysis of sodium exposed specimen confirmed a bulk penetration of sodium up to $20 \mathrm{~mm}$ depth with localized penetration of $44 \mathrm{~mm}$. A sacrificial limestone concrete layer of $50 \mathrm{~mm}$ thickness on structural concrete is recommended for sodium handling areas, for half an hour sodium exposure.

\section{INTRODUCTION}

Adequate safety measures are taken during design, fabrication, construction and operation stages of liquid sodium cooled fast breeder reactor (FBR). However, possibility of sodium leak from primary and secondary heat transport circuits of FBR is not completely ruled out. In the ventilated enclosures housing sodium pipelines such as steam generator building (SGB), spilled liquid sodium not only reacts with air causing fire but also interacts with structural concrete resulting thermo-hygro-chemo-mechanical degradation. In these air-filled enclosures, the structural concretes are protected from the sodium fire using steels/ refractory liners as well as sacrificial mortar layers as reported by Jeppson and Himeno et $\mathrm{al}^{1}$. Moreover, design and construction of sloping floor with sodium collection pit helps in minimizing the mass of sodium accumulated on the floor, its contact area with the concrete surface and exposure period. Installation of leak collection trays below the strategic pipelines and critical equipments/ vessels containing liquid sodium can circumvent the problems of physical contact between concrete surface and sodium. The motivation to use sacrificial protection layer on the structural concrete is primarily driven by key factors like economy, castability, easy and frequent demolition of affected concrete in the event of a sodium fire, disposability of debris as well as rapid reparability to enhance plant availability. Reviews of earlier research papers related to interaction of concrete with sodium fire by Fritke et al and Schultheiss has revealed that limestone concrete is more resistant to sodium attack than other types of concretes such as basalt and quartz $^{2}, 3$. The experimental results of preliminary experiments at $500^{\circ} \mathrm{C}$ on the interaction of sodium and concrete specimens containing limestone (Dolomite) as an aggregate were presented by Chasanov and Staahl $^{4}$. Cylindrical concrete specimens as per ASTMC192-69 were prepared and produced a concrete with water to cement ratio $=0.394$; gal water $/$ bag cement $=4.4$. Authors concluded that the partial dehydration of the concrete before immersion in sodium eliminated the cracking and spalling in the specimens. Casselman carried out series of experiments of sodium-concrete interaction under neutral atmosphere with the aim to acquire a better understanding of sodium-concrete interaction and of its consequences 5 . The study indicated that the sodium temperature plays an important roll at interfaces of sodium and concrete. However, concrete thickness does not appear as an important parameter. The study also indicated that the vertical interface shows a very different reaction rate evolution from one observed in horizontal interface. ZHANG Bin emphasized the concern on sodium-concrete interaction as a key safety-related issue in safety analysis of liquid metal cooled fast breeder reactors ${ }^{6}$. They described the chemical kinetics simulation under some hypotheses. The chemical kinetics model was integrated with the conservation equations to form a computer code to predict penetration depth, penetration rate, hydrogen flux, reaction heat from the concrete. Stress and deformation analysis due to the temperature rise of the concrete structures is carried out by Langhans ${ }^{7}$. The safety philosophy of the SNR-300 containment concept is explained in detail with hypothetical core disruption 
accidents combined with further failures in the containment safety systems are described. Hostis et al presented a specific approach for the prediction of long-term behaviour of structures used in the nuclear waste storage, reinforced concrete used for various purposes such as cell structures and containers ${ }^{8}$. The study discussed the experimental and theoretical approaches developed by them to understand mechanistic understanding and modeling of corrosion and mechanical behaviour of reinforced concrete. Noumowea et al presented the results of an experimental investigation to predict the behaviour of concrete intended for nuclear applications ${ }^{9}$. The experiments were carried out on cylindrical specimens of lime stone concrete and subjected to heating.cooling cycles at 110,210 and $310^{\circ} \mathrm{C}$. They concluded that the concrete containing limestone aggregates could be possibly used in applications involving elevated temperatures and reduction in the values of compressive strength and tensile strength and modulus of elasticity remained lower than $40 \%$ of the initial value even after a temperature of $310^{\circ} \mathrm{C}$. However, they reported the significant water loss at higher temperatures. Nguyen et al. carried out experimental and numerical studies to find out behavior of concrete for chemical and mechanical degradations due to the calcium leaching process ${ }^{10,11}$. To quantify the leaching evolution, the degradation depth is then measured at certain time intervals by means of a phenolphthalein solution. They carried out compression tests of concrete samples and observed a strong coupling between the calcium leaching and the mechanical behavior. The experimental results were used to validate the computation model and found in good agreement with the experimental results. It is clear from the literature that the many studies have been done so far on the lime stone concrete used FBRs for long duration to investigate various issues in inert atmosphere. However, the present study directed towards the development and testing of limestone concrete as sacrificial protection layer against sodium fire in SGB of Indian FBR plants. The burning sodium pool of initial depth $(140 \mathrm{~mm})$ is brought in contact with limestone concrete block with composition of $54 \% \mathrm{~W}$ of limestone as coarse aggregate, $21 \% \mathrm{~W}$ of river sand as fine aggregate, $17 \% \mathrm{~W}$ of 43 grade ordinary Portland cement and $8 \%$ of potable water. Experiments are conducted in test conditions conforming to realistic scenario in which an sodium leakage in the SG building of FBR can lead to combustion of $100 \mathrm{~mm}$ deep sodium pool in air on the concrete floor for a period of 30 minutes only due to well laid out sloping floors that leads all the leaked sodium to a collection pit and further to a large leak collection tank. The performance of the test concrete is assessed from the change in its physical, chemical and mechanical properties after interaction of sodium to lime stone concrete.

\section{SODIUM EXPOSURE TEST}

\section{Experimental setup description}

The experimental setup as shown in Fig.1, consists of a sodium tank connected to argon gas supply system with drain line positioned on concrete specimen which is kept on an online weighing balance. The test concrete specimens for the sodium exposure tests were cast with overall size of size $600 \times 600 \times 300 \mathrm{~mm}$ with inner cavity of $300 \times 300 \times 150 \mathrm{~mm}$ to maintain sodium level during the tests as shown in Fig. 2. Thermocouples were used during the tests to measure the temperatures on the inside concrete surface, bulk sodium and sodium flame temperature and an online data acquisition system was used to record the temperatures. About $12 \mathrm{~kg}$ of sodium was used in the tests to maintain a minimum height of sodium column of about $100 \mathrm{~mm}$ above the concrete for a period of 30 minutes. As the concrete block was positioned on an online weighing balance, it was possible to obtain the variations of total system mass (concrete block and sodium) on real time basis during the course of the experiment. This also confirms sucking back of left over sodium from the cavity and the respective rate with time details. While casting the test blocks, many reference concrete specimens of size $150 \times 150 \times 150 \mathrm{~mm}$ were also cast with the same mix design under identical casting conditions. These were subjected to compressive strength testing followed by chemical analysis to obtain background concentration of major chemical species. Average compressive strength of reference specimens at curing of 7 days and 28 days found to be $298 \mathrm{~kg} / \mathrm{cm}^{2}$ and $369 \mathrm{~kg} / \mathrm{cm}^{2}$ respectively.

\section{RESULTS AND DISCUSSIONS}

\section{A. Pre-test and post-test measurements}

Test conditions for each block are given in Table 1. Each concrete specimen was divided into grids of $75 \mathrm{~mm} \times 75 \mathrm{~mm}$ size all over the surfaces including cavity for non-destructive measurement 
Table 1. Summary of test conditions

\begin{tabular}{|l|c|c|c|c|}
\hline \multicolumn{1}{|c|}{ Test parameters } & \multicolumn{3}{|c|}{ Test No. } \\
\cline { 2 - 5 } & I & II & III & IV \\
\hline $\begin{array}{l}\text { Mass of concrete block, } \\
\text { kg }\end{array}$ & 232.4 & 230.9 & 228.95 & 230.25 \\
\hline $\begin{array}{l}\text { Mass of sodium } \\
\text { dumped, kg }\end{array}$ & 10.6 & 10.9 & 11.8 & 9.6 \\
\hline $\begin{array}{l}\text { Initial sodium } \\
\text { temperature, }\end{array}$ & 550 & 550 & 550 & 450 \\
\hline $\begin{array}{l}\text { Initial pool depth, mm } \\
\text { Sodium temperature in } \\
\text { cavity after 5 min. of } \\
\text { dumping, C }\end{array}$ & 115 & 118 & 120 & 110 \\
\hline $\begin{array}{l}\text { Sodium dumping } \\
\text { period, sec }\end{array}$ & 16 & 18 & 20 & 20 \\
\hline $\begin{array}{l}\text { Sodium contact period, } \\
\text { min }\end{array}$ & 30 & 30 & 30 & 30 \\
\hline $\begin{array}{l}\text { Mass of sodium sucked } \\
\text { out from cavity after } 30 \\
\text { min, kg }\end{array}$ & 8.2 & 8.6 & 7.9 & 6.4 \\
\hline $\begin{array}{l}\text { Sodium suction } \\
\text { duration, sec }\end{array}$ & 14 & 17 & 18 & 19 \\
\hline $\begin{array}{l}\text { Argon pressure, kg/cm } \\
\text { a. during dumping } \\
\text { b. during suction }\end{array}$ & +0.5 & +0.5 & +0.5 & +0.5 \\
\hline
\end{tabular}

purpose. Rebound hammer test and ultrasonic pulse velocity measurements were carried our at all the grids in all the four concrete blocks before and after sodium exposure, to analyze the degree of damage caused by both thermal and chemical attack. Post.test chemical analysis of samples taken from different depths from 5 holes (designated as A, B, C, D and E) in each concrete block were carried out to assess the depth of penetration of sodium. Core drilling was carried out to extract $50 \mathrm{~mm}$ diameter cores from sodium-exposed zone and ultrasonic pulse velocity measurements as well as compressive strength were measured. The readings were compared with standard cores of same size obtained from non-affected concrete blocks of same composition and cast environment. The peak temperatures at important locations and \% mass loss of concrete block are given in Table 2. The observations made at pre and post-test stages are given below for reference.
Table 2. Thermal conditions of sodium pool and concrete during the test

\begin{tabular}{|l|c|c|c|c|}
\hline \multirow{2}{*}{ Test variables } & \multicolumn{4}{c|}{ Test No. } \\
\cline { 2 - 5 } & I & II & III & IV \\
\hline $\begin{array}{l}\text { Maximum temp. at sodium } \\
\text { concrete interface, }{ }^{\circ} \mathrm{C}\end{array}$ & 650 & 752 & 709 & 716 \\
\hline $\begin{array}{l}\text { Maximum temp. at sodium air } \\
\text { interface, }{ }^{\circ} \mathrm{C}\end{array}$ & 745 & 757 & 738 & 646 \\
\hline $\begin{array}{l}\text { Maximum temp. at 30mm } \\
\text { depth of concrete from } \\
\text { interface }\end{array}$ & 207 & 295 & 294 & 304 \\
\hline$\%$ mass loss in concrete block & 2.41 & 0.61 & 0.92 & 0.87 \\
\hline
\end{tabular}

\section{B. Rebound hammer testing}

Rebound number represents the collective characteristics of compressive strength and hardness; higher is this value, better is the quality of concrete. The localized measurements of rebound number were conducted on cavity floor surface of each concrete block. The values of mean rebound number with standard deviations are presented in Table 3 for cavity floor of all the blocks along with those obtained in the pre-test phase at the same locations. The percentage reductions in the rebound number at the exposed cavity floor are estimated to be $3.8 \%, 16 \%, 2.1 \%$ and 9.9 $\%$ for the block number I, II, III and IV respectively which revealed that block II has undergone maximum damage. The reduction of rebound hammer number is attributed to the combined effect of decrease in the compressive strength and hardness of the concrete after sodium exposure. However, other blocks have not suffered any noticeable degradation. The detail analysis of standard deviation values confirms that scatter of rebound number values has shifted from narrow band before sodium exposure to broad band after exposure.

Table 3. Summary of Rebound Hammer Test Results for Cavity floor

\begin{tabular}{|l|c|c|c|c|}
\hline \multirow{2}{*}{} & \multicolumn{4}{|c|}{ Concrete Block Number } \\
\cline { 2 - 5 } & I & II & III & IV \\
\hline $\begin{array}{l}\text { Before } \\
\text { sodium } \\
\text { exposure }\end{array}$ & $39.3 \pm 3$ & $40.6 \pm 3.6$ & $41.4 \pm 3.2$ & $39.3 \pm 2.8$ \\
\hline $\begin{array}{l}\text { After } \\
\text { sodium } \\
\text { exposure }\end{array}$ & $37.8 \pm 5$ & $34.1 \pm 4.5$ & $40.5 \pm 3.9$ & $35.4 \pm 3.3$ \\
\hline
\end{tabular}


This also confirms the fact that localized and preferential damage predominates over bulk and uniform damage in a given block.

\section{Measurement of UPV and compressive strength for} core

Cylindrical core samples of $55 \mathrm{~mm}$ diameter and $150 \mathrm{~mm}$ length were subjected to test for UPV and compressive strength respectively. Compressive strength and UPV obtained for core samples from post-test and reference concrete specimens are listed in Table 4. The reduction in UPV and compressive strength were $7.1 \%$ and $29 \%$ respectively, indicating minor degradation in strength of sodium-exposed concrete. Thermal attack on concrete resulted in decomposition of hydrated cement paste with increase in porosity. Penetration of sodium into concrete led to de-bonding the cement-aggregate due to chemical reactions. All these factors have in combination led to deterioration of compressive strength and reduction in UPV values. Post-test chemical analysis Hot pool sodium coming in contact with concrete, immediately reacts with thermally driven out moisture from interior concrete. This reaction results in liquid sodium hydroxide, which is sparingly soluble in sodium and heavier. Hence, this settles down on the bottom of cavity floor as a physical layer between liquid sodium and concrete surface. The mixture of liquid sodium and sodium hydroxide penetrate in to the cavity floor through macro cracks formed due to thermal shock and loss of moisture. The depth of sodium penetration is considered as the depth of at with sodium monoxide level exceeds the background limit of $0.4 \%$ by mass. Chemical analysis of sodium present in the form of sodium monoxide in concrete samples collected by drilling holes is given in Table 5 (a-d) for all the four specimens. It is clear from this, in concrete block I, depth of local and preferential penetration of sodium

Table 4. Test results from measurement of ultrasonic pulse velocity and compressive strength test for post-test concrete block core samples and unexposed reference core sample

\begin{tabular}{|c|c|c|c|c|c|c|c|c|c|}
\hline \multirow{2}{*}{$\begin{array}{l}\text { Sl. } \\
\text { No }\end{array}$} & \multirow{2}{*}{$\begin{array}{c}\text { Test } \\
\text { Block } \\
\text { No. }{ }^{*}\end{array}$} & \multirow{2}{*}{$\begin{array}{l}\text { Mark on } \\
\text { Sample }\end{array}$} & \multirow{2}{*}{$\begin{array}{l}\text { Description } \\
\text { of core } \\
\text { sample }\end{array}$} & \multicolumn{2}{|c|}{$\begin{array}{l}\text { Size of cylindrical } \\
\text { core-sample in } \mathrm{mm}\end{array}$} & \multicolumn{2}{|c|}{$\begin{array}{l}\text { Longitudinal Ultrasonic } \\
\text { pulse velocity in } \mathrm{m} / \mathrm{s}\end{array}$} & \multicolumn{2}{|c|}{$\begin{array}{l}\text { Compressive strength } \\
\text { in } \mathrm{kg} / \mathrm{cm}^{2}\end{array}$} \\
\hline & & & & Dia & $\begin{array}{c}\text { Length } \\
\text { (average) }\end{array}$ & Individual & Average & Individual & Average \\
\hline 1 & $\begin{array}{l}\text { Std. } \\
\text { cube } \\
150 \\
\mathrm{~mm}\end{array}$ & \begin{tabular}{|l|} 
STD - 1 \\
STD - 2
\end{tabular} & $\begin{array}{l}\text { Pre-test } \\
\text { sample } \\
\text { Pre-test } \\
\text { sample }\end{array}$ & $\begin{array}{l}50 \\
50\end{array}$ & $\begin{array}{l}130 \\
150\end{array}$ & \begin{tabular}{|l|}
4530 \\
4620
\end{tabular} & \begin{tabular}{|l|}
4575 \\
\end{tabular} & $\begin{array}{l}402 \\
404\end{array}$ & 403 \\
\hline 2 & $B-1$ & $\begin{array}{l}B 1-S 1 \\
B 1-S 2 \\
B 2-S 4\end{array}$ & & $\begin{array}{l}55 \\
\text { " } \\
\text { " }\end{array}$ & $\begin{array}{l}150 \\
\text { " } \\
\text { " }\end{array}$ & $\begin{array}{l}4440 \\
4290 \\
4470\end{array}$ & 4400 & $\begin{array}{l}286 \\
260 \\
316\end{array}$ & 287 \\
\hline 3 & $B-2$ & $\begin{array}{l}\mathrm{B} 2-\mathrm{S} 1 \\
\mathrm{~B} 2-\mathrm{S} 2 \\
\mathrm{~B} 2-\mathrm{S} 4\end{array}$ & $\begin{array}{l}\text { Post-test } \\
\text { sample } \\
\text {-do- }\end{array}$ & " & "“ & $\begin{array}{l}4370 \\
4160 \\
4320\end{array}$ & 4283 & $\begin{array}{l}336 \\
265 \\
324\end{array}$ & 308 \\
\hline 4 & $B-3$ & $\begin{array}{l}\text { B3 - S1 } \\
\text { B3 - S3 } \\
\text { B3 - S4 }\end{array}$ & --do- & $\begin{array}{l}\text { " } \\
" \\
\text { " }\end{array}$ & " & $\begin{array}{l}4250 \\
4100 \\
4250\end{array}$ & 4200 & $\begin{array}{l}269 \\
248 \\
311\end{array}$ & 276 \\
\hline 5 & $B-4$ & $\begin{array}{l}B 4-S 2 \\
B 4-S 3 \\
B 4-S 1\end{array}$ & -do- & " & " & $\begin{array}{l}4160 \\
3940 \\
-- \\
\end{array}$ & $\begin{array}{l}4050 \\
--\end{array}$ & $\begin{array}{l}202 \\
324 \\
--\end{array}$ & 263 \\
\hline & & & $\begin{array}{l}\text { (While coring } \\
\text { saple broke), }\end{array}$ & & & & & & \\
\hline
\end{tabular}

B1, B2, B3 \& B4 - Indicates Test Block I, II, III and IV respectively.

S1, S2, S3 \& S4 - Indicates side walls of the cavity I, II, III and IV respectively in each block. 15 
Table 5. (a) Concentration of sodium as sodium monoxide in \% by mass for post-test block No I

\begin{tabular}{|c|c|c|c|c|c|}
\hline \multirow{2}{*}{$\begin{array}{c}\text { Sample } \\
\text { depth } \\
\text { interval } \\
(\mathrm{mm})\end{array}$} & \multicolumn{5}{|c|}{ Location of hole on cavity floor } \\
\cline { 2 - 6 } & A & B & C & D & E, \\
\hline 10 & 0.76 & 0.07 & 0.08 & 0.07 & 0.12 \\
\hline 20 & 2.48 & 0.34 & 0.31 & 0.13 & 0.16 \\
\hline 30 & 0.21 & --- & 0.07 & 0.06 & 0.10 \\
\hline 40 & 0.62 & 0.13 & 0.18 & 0.07 & 0.04 \\
\hline 50 & 0.14 & 0.12 & 0.04 & 0.04 & 0.10 \\
\hline
\end{tabular}

Table 5. (b) Concentration of sodium as sodium monoxide in \% by mass for post-test block No II

\begin{tabular}{|c|c|c|c|c|c|}
\hline $\begin{array}{c}\text { Sample } \\
\text { depth } \\
\text { interval } \\
\text { (mm) }\end{array}$ & \multicolumn{5}{|c|}{ Location of hole on cavity floor } \\
\cline { 2 - 6 } & A & B & C & D & E \\
\hline 10 & 1.29 & 3.46 & 1.87 & 2.45 & 1.57 \\
\hline 20 & 0.55 & 1.90 & 1.18 & 0.66 & 0.64 \\
\hline 30 & 0.53 & 0.45 & 0.56 & 0.43 & 0.60 \\
\hline 40 & 0.48 & 0.61 & 0.48 & 0.31 & 0.46 \\
\hline 50 & 0.29 & 0.34 & 0.58 & 0.18 & 0.39 \\
\hline
\end{tabular}

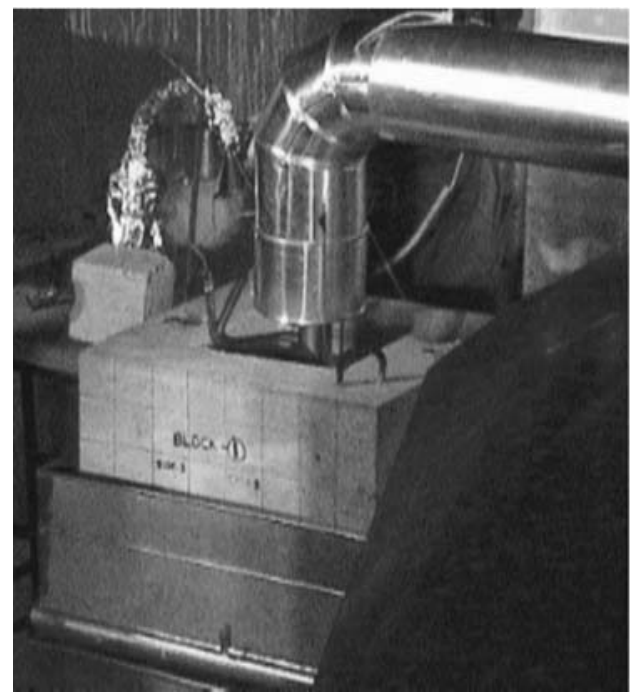

Fig. 1. Experimental setup 10

has registered a value of $44 \mathrm{~mm}$ whereas no uniform and bulk penetration of sodium has been observed in other four holes. Sodium has penetrated to the depth of $20 \mathrm{~mm}$ uniformly in all the five holes for block II, but no local and preferential penetration of sodium has
Table 5. (c) Concentration of sodium as sodium monoxide in \% by mass for post-test block No III

\begin{tabular}{|c|c|c|c|c|c|}
\hline \multirow{2}{*}{$\begin{array}{c}\text { Sample } \\
\text { depth } \\
\text { interval } \\
(\mathrm{mm})\end{array}$} & \multicolumn{5}{|c|}{ Location of hole on cavity floor } \\
\cline { 2 - 6 } & A & B & C & D & E \\
\hline 10 & 0.66 & 0.14 & 0.03 & 0.03 & 0.03 \\
\hline 20 & 0.39 & 0.13 & 0.05 & 0.09 & 0.04 \\
\hline 30 & 0.71 & 0.10 & 0.16 & 0.17 & 0.10 \\
\hline 40 & 0.79 & 0.08 & 0.15 & 0.04 & 0.04 \\
\hline 50 & 0.57 & 0.14 & 0.10 & 0.02 & 0.08 \\
\hline
\end{tabular}

Table 5. (d) Concentration of sodium as sodium monoxide in \% by mass for post-test block No IV

\begin{tabular}{|c|c|c|c|c|c|}
\hline \multirow{2}{*}{$\begin{array}{c}\text { Sample } \\
\text { depth } \\
\text { interval } \\
(\mathrm{mm})\end{array}$} & \multicolumn{5}{|c|}{ Location of hole on cavity floor } \\
\cline { 2 - 6 } & A & B & C & D & E \\
\hline 10 & 1.52 & 1.64 & 1.76 & 1.44 & 1.40 \\
\hline 20 & 0.46 & 0.37 & 0.31 & 0.43 & 0.33 \\
\hline 30 & 0.20 & 0.21 & 0.28 & 0.18 & 0.25 \\
\hline 40 & 0.17 & 0.12 & 0.13 & 0.12 & 0.19 \\
\hline 50 & 0.13 & 0.12 & 0.32 & 0.12 & 0.15 \\
\hline
\end{tabular}

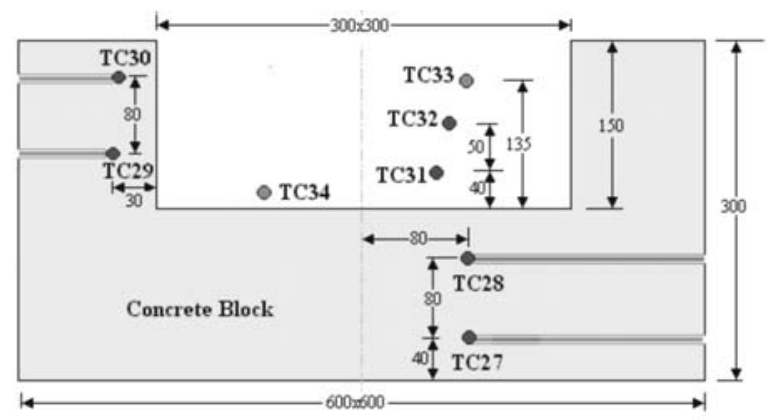

Fig. 2. Dimensional details and $T / C$ positions of concrete block 11

occurred. Similarly sodium has penetrated to the maximum depth of $50 \mathrm{~mm}$ in one hole only out of five holes drilled in the concrete block III. Negligible depth of sodium penetration was noticed in other four holes. In block IV, uniform penetration of sodium has taken place to the depth of $10 \mathrm{~mm}$ in all the five holes without any local and preferential penetration. 


\section{CONCLUSION}

The experimental investigations were carried out on the limestone concrete specimens to study the degradation behaviour due to liquid sodium at high temperature for limited time period. Measurements of compressive strength, Rebound number, UPV and chemical analysis were done to assess the overall degradation of the concrete. No visible cracks on the cavity floor and inner surfaces of the cavity walls were noticed for all the blocks. The rebound hammer data confirmed that no significant damage has occurred in the cavity floor. Chemical analysis on the sodium penetration into cavity floor has revealed that pattern of penetration varied from block to block from uniform and bulk in some cases to even local and preferential penetration in others. Sodium penetration was uniform up to depth of $20 \mathrm{~mm}$. The reduction in UPV and compressive strength were $7.1 \%$ and $29 \%$ respectively, indicating mechanical degradation in strength of sodium-exposed concrete. The present study has concluded that limestone concrete of $50 \mathrm{~mm}$ thickness adequate for protection of structural concrete under thermal and chemical attack of sodium during sodium fire for 30 minutes.

\section{REFERENCES}

[1] Himeno, Y. et al, 1990. Development of ceramic liner for FBR building. International Fast Reactor Safety Meeting, Vol 1, P-251

[2] Fritke, H. W. et al, 1983. Experimental investigation of sodium-concrete interaction and mitigating protective layers. Transaction of the $7^{\text {th }}$ International Conference of structural Mechanics in Reactor Technology, vol H, No $3 / 3$, P. 135

[3] Schultheiss, G. F., 1983. Investigation of sodium concrete interaction and the effect of different by-products. Report no. GKSS 83/E/59.

[4] Chasanov M.G. and Staahl G.E., 1977 Sr, High temperature sodium-concrete interactions, Journal of Nuclear Materials 66, 217-220

[5] Casselman C, 1981 Consequences of Interaction between Sodium and Concrete, Nucl. Eng. Des., 68, 207-212.

[6] ZHANG Bin, ZHU Ji-Zhou, SHAN Jian-Qiang, WANG Xue-Rong, 2006 Simulation of chemical kinetics in sodium-concrete interactions, Nuclear Science and Techniques. Vo1.17, 53-60.

[7] Langhans J., 1989 Fast breeder reactor building, severe accident loading and ultimate capacity, Nuclear Engineering and Design 117, 51-65.

[8] Hostis V.Li., Foct F., Dillmann P., 2008 Corrosion behaviour of reinforced concrete: Laboratory experiments and archaeological analogues for long-term predictive modeling, Journal of Nuclear Materials 379, 124-132.

[9] Albert Noumowea, Rafat Siddiqueb, Guillaume Ranc, 2009 Thermo-mechanical characteristics of concrete at elevated temperatures up to 310 .C, Nuclear Engineering and Design 239, 470.476.

[10] Nguyen, V.H. Colina, H. Torrenti J.M., Boulay C., Nedjar B., 20072083.2089 Chemo-mechanical coupling behaviour of leached concrete Part I: Experimental results,Nuclear Engineering and Design 237.

[11] Nguyen V.H., Nedjar B., Torrenti J.M., 2007 2090.2097.9 Chemo-mechanical coupling behaviour of leached concrete Part II: Modelling, Nuclear Engineering and Design 237.

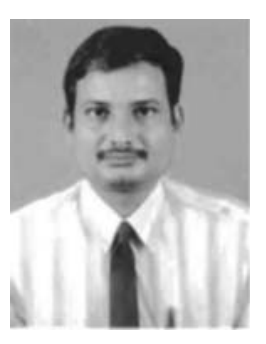

Dr. Anil Kumar Sharma is a Scientific Officer at the Department of Atomic Energy (DAE), Indira Gandhi Center for Atomic Research, at Kalpakkam since 1995. Prior to joining DAE, Dr. Sharma worked as an Engineer at Ms Escorts Ltd, Faridabad for four years in the CNC group. He completed M.Tech (Mechanical Engg.) from Indian Institute of Technology (IIT) Madras in 2003 and subsequently obtained Ph.D. from Indian Institute of Technology Madras in 2007. During both his degrees, Dr. Sharma was working on numerical heat transfer and fluid dynamics problems. $\mathrm{He}$ has published over 10 international journal and 20 international and national conference papers. He has been engaged in design and development of high temperature experimental systems. Dr. Sharma has vast experience of carrying out computational and experimental thermal hydraulics studies related to safety issues of Indian Nuclear Fast Reactors. 